\title{
Firsts records of melanistic genet (Genetta genetta L., 1758) in North Portugal
}

\author{
Paulo Barros ${ }^{1}$, Abrandino Ledesma $^{2}$ \& Luis Moreira ${ }^{3}$ \\ 1 Laboratory of Applied Ecology,Centre for the Research and Technology of Agro-Environment and Biological Sciences(CITAB). \\ University of Trás-os-Montes and Alto Douro (UTAD), 5000-801, Vila Real, Portugal. \\ 2 Rua do fundo do povo №11 Limãos 5340-400 \\ 3 Apartado 1010, EC Cantarias, 5300-907 Bragança.
}

\section{Correspondence}

P. Barros

E-mail: pbarros@utad.pt

Received: 25 July 2014

Accepted: 31 October 2014

Published on-line: 1 December 2014

\section{Resumen}

Primeras citas de melanismo en gineta (Genetta genetta L., 1758) en el norte de Portugal

El melanismo u otra coloración atípica raramente se observa en mamíferos y, concretamente, en gineta (Genetta genetta). La observación de especímenes con este fenotipo de melanismo está restringido a algunos registros en la Península Ibérica. En esta nota describimos los primeros registros de ginetas melánicas en el norte de Portugal: una encontrada muerta en una carretera y dos fotografiadas con cámaras trampa. Estas observaciones enfatizan la importancia de estos registros para la clarificación de la distribución y abundancia de especímenes con estas características fenotípicas. El melanismo puede ser resultado de la endogamia de la población, de modo que investigación en la genética en esta especie sería de mucho interés.

Palabras clave: Melanismo, Gineta, Portugal, Mediterráneo.

\begin{abstract}
The melanistic or other atypical colours are rarely observed in mammals and also in genets (Genetta genetta). The observation of specimens with these phenotypic characteristics is restricted to a few records in the Iberian Peninsula. In this note, we describe the first records of melanistic genets in the North of Portugal: one found dead in a road and two photographed with photo trapping cameras. These observations emphasise the importance of these records to clarify the distribution and abundance of specimens with these phenotypic characteristics, as well as the patterns of introduction of the common genet into Europe. Melanism may indicate population inbreeding therefore further research on genetics of this species could be of interest.
\end{abstract}

Key words: Melanistic, Genet, Portugal, Mediterranean. 


\section{Introduction}

In mammals, the colour of hairs, skin and eyes stems from the biosynthesis of a range of melanin pigments occurring in melanocytes. Such pigments arise from a common metabolic pathway where a series of enzymes is involved in different oxidation steps catalyzed by tyrosinase (Gauber \& Dufour 2013). Therefore, mutations that affect melanin biosynthesis have a global impact on the organism, including on retinal pigments. The bestknown mutation of this type is probably the albino, where the loss of the oxidative function of tyrosinase results in a white phenotype with red eyes (Gauber \& Dufour 2013).

Melanocytes synthesize two types of melanin, namely eumelanin (brown/black) and phaeomelanin (red/yellow), both requiring the action of tyrosinase (Ito \& Wakamatsu 2003). Melanocytes from hair follicles may switch between eumelanin and phaeomelanin synthesis, a mechanism responsible for the rich coat colour polymorphism observed in natural populations of mammals (Barsh 2001) and which is likely to be involved in adaptive cryptic colorations (Singaravelan et al. 2010).

The European melanistic genet cases (Genetta genetta L., 1758) are reviewed in Gaubert \& Mézan-Muxart (2010). These reported cases of melanism are localized, namely in the Iberian Peninsula and Europe (Duarte \& Rubio 1999, Gaubert \& Mézan-Muxart 2010, Barrull \& Mate 2012), but may not be as rare as it is believed (Delibes et al. 2013). However, no melanistic cases have ever been documented within the native range of the common genet (i.e. sub-Saharan Africa, Maghreb and Peninsular Arabia) (Gaubert \& Mézan-Muxart 2010).

The genet is a native mammal of Africa, however, this idea is not the unique and consensual in the academic community and is the only species of the Viverridae family that occurs in Europe, with a size similar to that of a small cat, slender body, short legs and a tail as long as the rest of the body (Sáez \& Montiel 2006). In Europe, this species occurs in the whole of mainland Portugal and Spain, part of France, Andorra and north-west Italy (Fig. 1), as well as the Mediterranean islands of Majorca, Ibiza, and Cabrera (Balearic Islands). In addition, there are also scattered records from Belgium, Switzerland, Holland and Germany (Delibes 1999). The genet is commonly found in suitable habitats throughout the Iberian Peninsula (Palomo \& Gisbert 2002). It is one of the most common small carnivores in its native range, moderately abundant in Europe and has increasing populations in France (Delibes 1999).

In this note we describe the first records of melanistic Genetta genetta in the North of Portugal (Fig. 1).

\section{Results}

On 21th March 2009, near the village of Grijó de Parada (41 $\left.42^{\circ} 48.92^{\prime \prime} \mathrm{N}, 6^{\circ} 39^{\prime} 36.37^{\prime \prime} \mathrm{W}\right)$, municipality of Bragança, we photographed a melanistic genet with a photo trapping camera (Fig. 2A). On

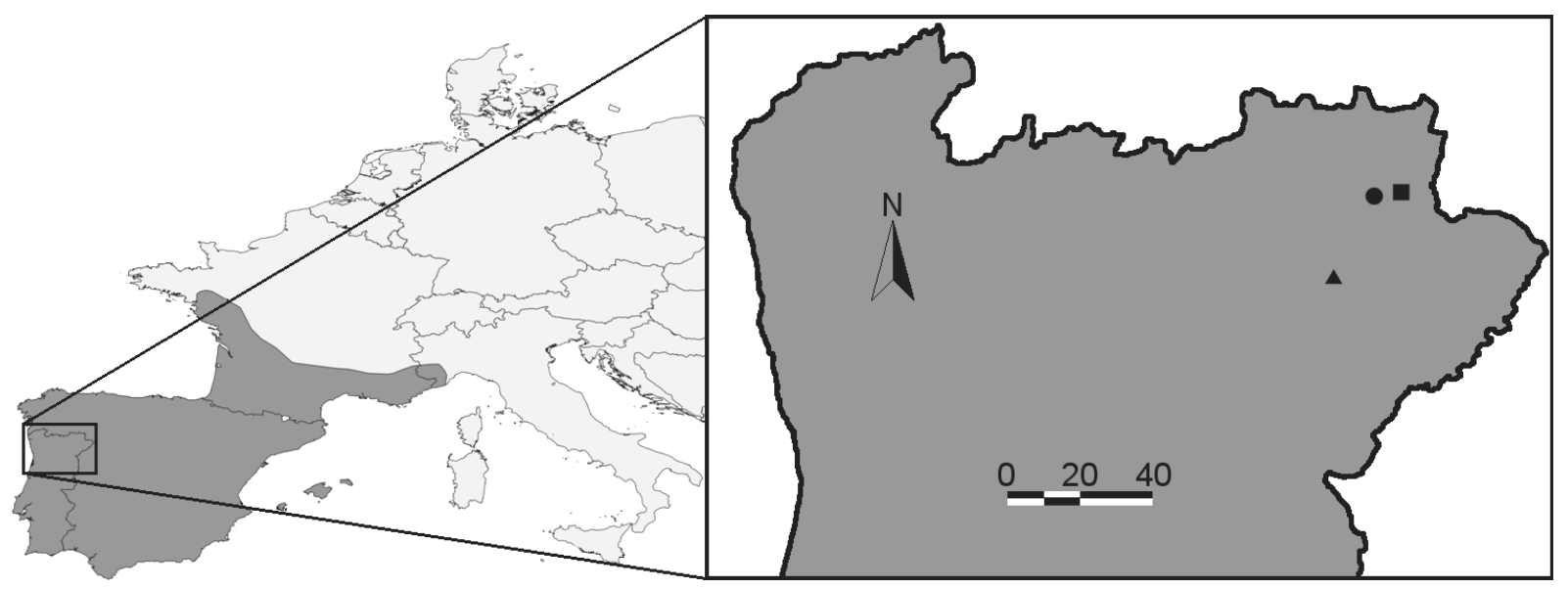

Figura 1. Distribución (gris oscuro) de Genetta genetta en Europa (UICN, 2008) y localización de los especímenes registrados: • Faílde, 2013; வ Limãos, 2011; - Grijó de Parada, 2009.

Figure 1. Distribution (dark grey) of Genetta genetta in Europe (UICN, 2008) and location of our melanistic specimen records: • Faílde, 2013; வ Limãos, 2011; - Grijó de Parada, 2009. 
3th March 2011, in the municipality of Macedo de Cavaleiros, we found a dead adult male in the road near the Village of Limãos, $\left(41^{\circ} 31^{\prime} 30.82^{\prime \prime} \mathrm{N}\right.$, $6^{\circ} 51^{\prime} 42.56^{\prime \prime}$ W, Fig. 2B). In fact, in the study area, this species is one of three species of carnivorous most affected by road mortality, being surpassed only by the red fox (Vulpes vulpes L., 1758 ) and the beech marten (Martes foina Erxleben, 1777) (Operestradas XXI 2013). In 2013, we photographed another melanistic individual with a photo trapping camera (once in March, five times in April and twice in May) near

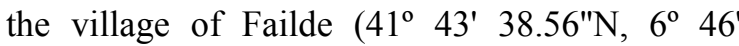
27.55"W, Fig. 2C), municipality of Bragança. The distance between the two locations where we photographed the melanistic genets in Bragança is approximately $9 \mathrm{~km}$ and between these and the record of the dead genet in Macedo de Cavaleiros the distance is approximately $26 \mathrm{~km}$ (Fig. 1). In the three genets photographed we observed a different pattern of melanism, in fact several types of melanistic genets are found in other study (Delibes et al. 2013)

The habitat where these genets were found consists of Mediterranean vegetation: a mixture of evergreen forests and deciduous forests. Agriculture relies mainly on plantations of Olea europaea L. (Macedo de Cavaleiros) and Castanea sativa Mill. (Bragança), permanent pastures and forage crops for livestock feeding.

Ecological factors that have been proposed as possibly acting on the expression of melanism in mammals relate to extreme temperature, humidity or altitude (Caro 2005, Millien et al. 2006), notably in genets (Webb 1947). However, the heterogeneity of the environment where melanistic individuals have been cited, at least in the Iberian Peninsula, is not coherent with the hypothesis that climatic factors are relevant in the expression of this phenotype (Barrull \& Mate 2012). On the other hand, inbreeding or the small number of individuals introduced could be more plausible triggers (Gaubert et al. 2009, Gaubert et al. 2010).In Portugal there are only three records published, restricted to the central and northern parts of the country, namely, Alfeite (Seabra 1900), Penamacor and São Vicente (Themido 1928), and few from different regions of Spain: Sierra Morena (Graells 1897), Arganda del Rey (Cabrera 1905), in the provinces of Orense, Cádiz, Málaga and Salamanca (Duarte \& Rubio 1999) and La Rúa

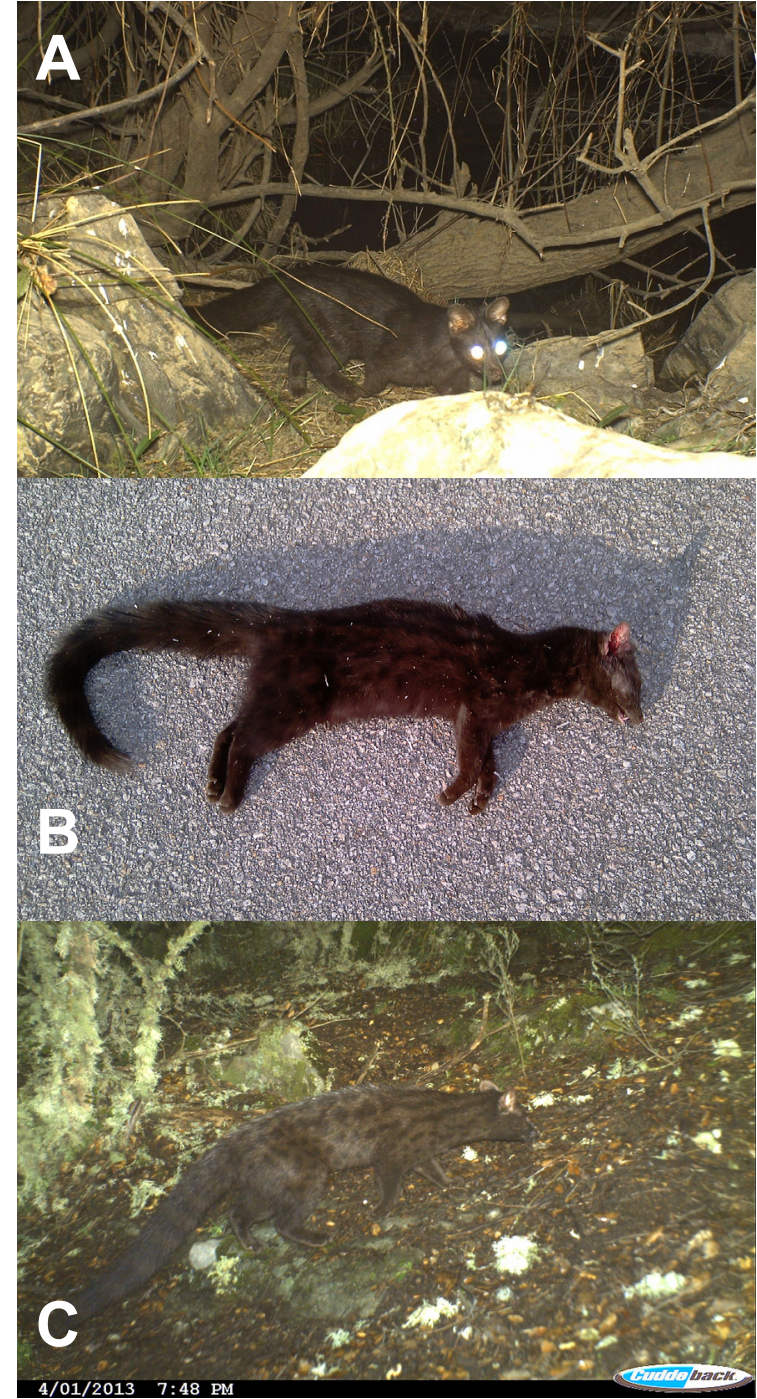

Figura 2. Genetta genetta melánica. A: Fotografiada con cámara automática en 2009; B: Encontrada muerta en carretera; C: Fotografiada con cámara automática en 2013.

Figure 2. Melanistic Genetta genetta. A: Photographed with a photo trapping camera in 2009; B: Found dead on the road; C: Photographed with a photo trapping camera in 2013

(Orense), Villoldo (Palencia) and Jerte Valley (Cáceres) (Delibes et al. 2013).

The observation of these melanistic genet specimens may contribute towards clarifying the distribution and abundance of specimens with these phenotypic characteristics as well as the patterns of introduction of the common genet into Europe (Gaubert \& Mézan-Muxart 2010).

\section{Acknowledgements}

We thank Luís Braz and Hélia Vale-Gonçalves for the valuable suggestions on an earlier draft version. We are grateful to the anonymous revie- 
wers for their valuable comments and suggestions to improve the quality of the paper.

\section{References}

Barrull J \& Mate I. 2012. Primera cita de gineta (Genetta genetta L., 1758) melánica en Cataluña. Galemys 24: 74-75.

Barsh G. S. 2001. Coat color mutations, animals. In Encyclopedia of Genetics (Brenner S \& Miller JH, eds.) Academic, pp. 397-401.

Cabrera A. 1905. Sobre las ginetas españolas. Boletin de la Real Sociedad Española de Historia Natural 19:259-267.

Caro T. 2005. The adaptive significance of coloration in mammals. BioScience 55: 125-136.

Delibes M. 1999. Genetta genetta. in The Atlas of European Mammals (Mitchell-Jones AJ, Amori J,. Bogdanowicz W, Kryštufek $B$, Reijnders $\mathrm{PJH}$, Spitzenberger F, Stubbe M, Thissen JBM, Vohralík V \& Zima J, eds),. Academic Press, London, UK.

Delibes M, Mézan-Muxart V \& Calzada J. 2013. Albino and melanistic genets (Genetta genetta) in Europe. Acta Theriol. 58: 95-99.

Duarte G \& Rubio PJ. 1999. Sobre la captura de una gineta (Genetta genetta L. 1758) melánica. Galemys 11(1): 44-46.

Furumura M, Sakai C, Abdel-Malek Z, Barsh GS \& Hearing VJ. 1996. The interaction of Agouti signal protein and melanocyte stimulating hormone to regulate melanin formation in mammals. Pigment Cell Research 9: 91-203.

Gauber P \& Dufour S. 2013.First report of a chinchilla phenotype in Viverridae (Carnivora). Small Carnivore Conservation 48: 92-95.

Gaubert P \& Mézan-Muxart V. 2010. Where have the "black genets" gone? A likely restriction of melanistic cases of the common genet (Genetta genetta) to its introduced range. Mammalian Biology 75: 353-357.

Gaubert P, Godoy J, Del Cerro I \& Palomares F. 2009. Early phases of a successful invasion: mitochondrial phylogeography of the common genet (Genetta genetta) whitin the Mediterranean Basin. Biological
Invasions 11: 523-546.

Graells M. 1897. Fauna mastologica iberica. Memorias de la Real Academia de Ciencias exactas, físicas, y naturales de Madrid 17: 1-806.

Ito S \& Wakamatsu K. 2003. Quantitative analysis of eumelanin and pheomelanin in humans, mice, and other animals: a comparative review. Pigment Cell Research16: 523-531.

IUCN (International Union for Conservation of Nature) 2008. Genetta genetta. The IUCN Red List of Threatened Species. Version 2014.1.

Millien V, Lyons S K, Olson L, Smith FA, Wilson AB, Yom-Tov Y. 2006. Ecotypic variation in the context of global climate change: revisiting the rules. Ecology Letters 9: 853-869.

Operestradas XX. 2013. Monitorização de mortalidade fauna silvestre. Subconcessão Auto-Estrada transmontana. 37pp

Palomo LJ \& Gisbert J. 2002. Atlas de los Mamíferos Terrestres de España. Madrid : Dirección General de Conservación de la Natureza-SECEM-SECEMU.

Rivas-Martínez S, Fernández-González F \& Sánchez-Mata D. 1987. El Sistema Central: de la Sierra de Ayllón a Serra da Estrela. En La vegetación de España (M. Peinado \& S. Rivas-Martínez, Eds.) . Publicaciones Universidad de Alcalá, Madrid, pp. 419-451

Sáez P \& Montiel S. 2006. Sobre la presencia de ginetas (Genetta genetta, Linnaeus, 1758) y letrinas en zonas humanizadas. Galemys 18:1-2

Seabra AF. 1900. Mammiferos de Portugal no Museu de Lisboa. Jornal de Sciencias Mathematicas, physicas e Naturaes, Segunda Série 6: 90-115.

Singaravelan N, Pavlicek T, Beharav A, Wakamatsu K, Ito $S$ \& Nevo E. 2010. Spiny mice modulate eumelanin to pheomelanin ratio to achieve cryptic coloration in "Evolution Canyon," Israel. PLoS ONE 5(1): (e8708) 1-7

Themido AA. 1928. Catalogue des Carnivores existants dans les collections du Muséum Zoologique de Coimbra. Memórias e Estudos do Museu Zoológico da Universidade de Coimbra 1:5-25.

Webb C S. 1947. Neumann's genet. Zoo Life London 2, 108. 